\title{
Modelling of Hybrid Method for VOC Removal from Process Wastewater: Distillation and Hydrophilic Pervaporation
}

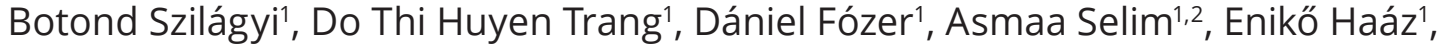 \\ András József Tóth ${ }^{1,3 *}$

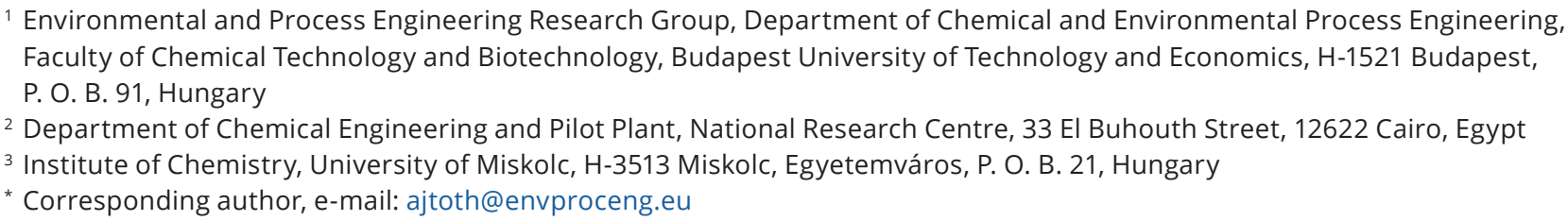

Received: 28 October 2019, Accepted: 30 January 2020, Published online: 20 April 2020

\begin{abstract}
The study is motivated by the industrial problem from pharmaceutical industry, which is ethanol and methanol removal from process wastewater. To complete this goal hybrid method is investigated and optimized. Two distillation columns are sufficient for separation of alcohol-water mixture. Suitable water can be purified as bottom product of first column. Ethanol and methanol purification is achieved with combination of second distillation column and pervaporation. The target of this research is to rigorously model and optimize the separation of water-ethanol-methanol ternary mixture in professional flowsheet simulator environment. The minimal sufficient membrane transfers area and number of minimal theoretical stages of the columns are determined. Cost estimation is also investigated according to Douglas methodology. Considering the simulation and economic results it can be determined that, the hybrid configuration is suitable for separation of ternary mixture in 99.5 weight percent purity.
\end{abstract}

Keywords

ethanol and methanol removal, process wastewater, hydrophilic pervaporation, mathematical modelling, computer simulation

\section{Introduction}

Separation of water and alcohol mixtures can be considered well-known example of hydrophilic pervaporation operation in chemical and related industries [1,2]. Although more references reported that Pervaporation (PV) method is applied for separating ethanol (EtOH) / water and methanol $(\mathrm{MeOH}) /$ water binary mixtures, but there is nearly no study and widespread technology for separating water-ethanol-methanol ternary mixture. Ethanol and methanol can be considered as Volatile Organic Compound (VOC).

The removal of organic compounds from aqueous solutions is particular interest for fermentation, treatment of wastewater water and recycling processes [3-9].

The target of this study is to optimize the separation of water-ethanol-methanol ternary mixture with combination of distillation and hydrophilic pervaporation method in professional flowsheet environment.

Ethanol forms minimal boiling azeotropic mixture with water. EtOH content above 96 weight\% cannot be achieved with conventional distillation techniques $[7,10]$. In contrasts, methanol and water is zeotropic mixture. Hybrid method of distillation and hydrophilic pervaporation has proven to be economically viable for separation of binary azeotropic mixtures [11]. If the azeotropic composition can be approached with distillation, then the distillate product (D) can be further purified applying PV. Hydrophilic PV proved to effective solution for separation of ethanol/water binary mixture in contrast to distillation [7].

Pervaporation is a relatively new technology, where the mixture to be treated is vaporized at low pressure on the permeate side of the membranes and the separation of the mixtures progresses by preferential sorption and diffusion phenomenon of the desired component through the dense membranes [7]. Vacuum pump on the permeate side can maintain the low vapor pressure $[7,12,13]$. Pervaporation is capable for the separation of many organic aqueous systems [14-17]. 
The unit operation is mainly used for dehydration of organic compounds from its aqueous mixtures [18-20], removal of low concentration organics from water [21-23] and organic-organic separation [24-26]. Depending on the main permeating compound two main areas of pervaporation process can be classified: hydrophilic and organophilic pervaporation [27-30].

This unit operation has the specialties such as no-pollution and energy-saving, simply actualization and high separation which are difficult to obtain by other conventional technologies [7].

The pervaporation measurements can be achieved in continuous and batch configuration [31]. Table 1 shows the comparison of both solution.

Pervaporation can have advantages over distillation method because of the capability to separate azeotropic mixtures and its lower energy demand. Generally, distillation can be used to remove VOCs from water and pervaporation is also suitable for this problem [32]. Furthermore, the pervaporation operation has usually lower operating temperatures and the separation does not require an extra added component (such e. g. azeotropic and/or extractive distillation) [33-40]. As it can be determined, pervaporation is considered as the competitive separation alternative of distillation [7].

\section{Material and methods}

In the pharmaceutical sector it is an important problem that methanol and ethanol should be separated from aqueous mixture. The investigated pharmaceutical process wastewater (PWW) had the following composition: 20 weight percent $(\mathrm{wt} \%)$ methanol, $20 \mathrm{wt} \%$ ethanol and $60 \mathrm{wt} \%$ water. $1000 \mathrm{~kg} / \mathrm{h}$ PWW must be treated and the product purities are $99.5 \mathrm{wt} \%$. Continuous operation was used for separation because of the large amount of initial process wastewater and the products goal, which is maximal enrichment quality (see Table 1). ChemCAD professional

\begin{tabular}{lc} 
Table 1 Continuous versus batch configuration of pervaporation [31] \\
\hline Continuous pervaporation & Batch pervaporation \\
\hline $\begin{array}{l}\text { Primary product goal: maximal } \\
\text { enrichment/extract quality }\end{array}$ & $\begin{array}{c}\text { Primary product goal: } \\
\text { maximum recovery }\end{array}$ \\
$\begin{array}{l}\text { No (significant) pre-treatment of } \\
\text { feed required }\end{array}$ & $\begin{array}{c}\text { Considerable pre-treatment of } \\
\text { raw material required }\end{array}$ \\
$\begin{array}{l}\text { Retentate holds full value during } \\
\text { post-hydrophilic pervaporation } \\
\text { processing }\end{array}$ & $\begin{array}{c}\text { Retentate considered as } \\
\text { low-value (by-)product }\end{array}$ \\
$\begin{array}{l}\text { Abundant availability of (liquid) } \\
\text { raw material }\end{array}$ & Restricted availability of (liquid) \\
\hline
\end{tabular}

flowsheet simulator was applied for the investigation of ternary mixture separation. UNIQUAC thermodynamic model was used in the case of SCDS distillation column. Table 2 shows the binary UNIQUAC parameters.

The fundamental (Model I) and the exponential Rautenbach model (Model II) were also applied for modelling of hydrophilic pervaporation [15]. Equation (1) shows the equation of fundamental Rautenbach model.

$$
J_{i}=1 /\left(1+\left[\bar{D}_{i} /\left(Q_{0} \times p_{i 0} \times \bar{\gamma}_{i}\right)\right]\right) \times\left(\bar{D}_{i} / \bar{\gamma}_{i}\right) \times\left(\left[p_{i 1}-p_{i 3}\right] / p_{i 0}\right)
$$

The following equation introduces the improved Rautenbach model [41]:

$$
\begin{aligned}
& J_{i}=1 /\left(1+\left\{\left[\bar{D}_{i} \times \exp \left(B \times x_{i 1}\right)\right] /\left(Q_{0} \times p_{i 0} \times \bar{\gamma}_{i}\right)\right\}\right) \\
& \times\left[\bar{D}_{i} \times \exp \left(B \times x_{i 1}\right)\right] / \bar{\gamma}_{i} \times\left(\left(p_{i 1}-p_{i 3}\right) / p_{i 0}\right)
\end{aligned}
$$

The PV model verification can be taken with objective function (OF), which is minimized the difference of the modelled and the measured values [42].

$\mathrm{OF}=\sum_{i=1}^{n}\left(\left(J_{i, \text { measured }}-J_{i, \text { modelled }}\right) / J_{i, \text { measured }}\right)^{2}$

Table 3 and Table 4 show the estimated parameters of the mentioned semi-empirical models with Sulzer PERVAPTM 1510 membrane. The experimental conditions can be found in the paper of Valentínyi et al. [15].

It can be seen Model II is much more appropriate for description of pervaporation than Model I in both cases.

Hybrid method has been selected for separation of PWW. The flowsheet can be seen in Fig. 1.

The optimized parameters of complex separation processes were: reflux ratio, number of theoretical stages, feed tray number and effective membrane transfer area $(A)$. The minimized Total Annual Cost (TAC) must be found as the objective function of the model optimization. The methodology of Tóth [7, 11] and Douglas equations [43] were applied for cost estimation with Marshall\&Swift index of 2018 (M\&S = 1638.2 [44]), while pump costs were determined by industrial data [7]. Membrane area-price function was determined on industrial data too and applied

Table 2 UNIQUAC parameters of investigated binary pairs

\begin{tabular}{lcccccc}
\hline$I$ & $J$ & $\begin{array}{c}\text { Sub } \\
\text { Type }\end{array}$ & $U_{i j}-U_{j j}$ & $U_{j i}-U_{i i}$ & $\begin{array}{c}p \text { range } \\
{[\mathrm{kPa}]}\end{array}$ & $\begin{array}{c}T \text { range } \\
{\left[{ }^{\circ} \mathrm{C}\right]}\end{array}$ \\
\hline \multirow{2}{*}{ Water } & \multirow{2}{*}{$\mathrm{MeOH}$} & $\mathrm{VLE}$ & -10.377 & 95.259 & $\begin{array}{c}0.1- \\
100\end{array}$ & $\begin{array}{c}25- \\
100\end{array}$ \\
& & & & & $0.1-$ & $20-$ \\
Water & \multirow{2}{*}{$\mathrm{EtOH}$} & $\mathrm{VLE}$ & 232.01 & 50.88 & 100 & 100 \\
& & & & & $0.5-$ & $25-$ \\
$\mathrm{MeOH}$ & \multirow{2}{*}{$\mathrm{EtOH}$} & $\mathrm{VLE}$ & -181.286 & 247.378 & 100 & 100 \\
\hline
\end{tabular}


Table 3 Estimated parameters and minimized objective functions in the case of Model I [15]

\begin{tabular}{lcc}
\hline & Water & Ethanol \\
& binary mixture \\
\hline Transport coefficient $\left[\mathrm{kmol} / \mathrm{m}^{2} \times \mathrm{h}\right]$ & $3.34 \mathrm{E}-04$ & $1.89 \mathrm{E}-07$ \\
Activation energy $[\mathrm{kJ} / \mathrm{kmol}]$ & 80042 & 95414 \\
OF [-] & 0.93 & 5.03 \\
\hline
\end{tabular}

Table 4 Estimated parameters and minimized objective functions in the case of Model II [15]

\begin{tabular}{lcc}
\hline & $\begin{array}{c}\text { Water } \\
\text { binary }\end{array}$ & $\begin{array}{c}\text { Ethanol } \\
\text { mixture }\end{array}$ \\
\hline Transport coefficient $\left[\mathrm{kmol} / \mathrm{m}^{2} \mathrm{~h}\right]$ & $2.02 \mathrm{E}-04$ & $1.93 \mathrm{E}-05$ \\
Activation energy $[\mathrm{kJ} / \mathrm{kmol}]$ & 77877 & 128572 \\
Exponential parameter [-] & 2.63 & 8.68 \\
OF [-] & 0.14 & 2.25 \\
\hline
\end{tabular}

for the calculation of the investment costs of membrane modules $[5,45]$. Two and half years were taken as membrane depreciation time, because membranes should be generally replaced in approximately every 2-5 years [7]. 10 -year amortization of investment cost was assumed for the total cost estimation [45].

First step, the initial process wastewater was entered into the Column I in the case of hybrid method, where suitable treated water can be got as bottom product $(W)$. The alcohol-rich intermediate distillate $(D)$ was purified further in Column II. Sufficient ethanol content can be reached using hydrophilic pervaporation. Retentate product $(R)$ contains ethanol in $99.5 \mathrm{wt} \%$ and the permeate stream $(P)$ was mixed into the feed stream of distillation Column II. The sufficient methanol concentration $(99.5 \mathrm{wt} \%)$ can be received in distillate product of Column II.
Permeate and feed pressures were the following, 0.008 bar and 3 bar. The used feed temperature in membrane modules was $70{ }^{\circ} \mathrm{C}$. Additional apparatuses were also needed for pervaporation process $[7,45]$. The pressure and temperature had to be increased for the operational level prior to the first membrane unit with pump and heat exchanger, because the feed $(F)$ had atmospheric conditions, 1 bar and $20^{\circ} \mathrm{C}$. Retentate stream was reheated after each membrane unit by further heat exchangers [46], except for the last module. Permeate flows leaving the pervaporation apparatuses were collected and condensed with cooler. At last, post coolers and valves decreased again in atmospheric pressure and temperature of Water, Ethanol, and Methanol products [36].

Before computer simulation, the distillation solution of Column I was experimentally verified. The separation process was examined with laboratory distillation column.

The main parameters of the column were the followings: structured packing with diameters of $0.4 \mathrm{~m}$. The laboratory column had 10 number of theoretical stages based on measurement carried out by binary methanol-water mixture. Fig. 2 shows the laboratory experimental column.

The mixture was entered into the middle of the tower. The apparatus heating was controlled with a $300 \mathrm{~W}$ heating basket. The alcohol concentration of the feed and products were measured with Shimadzu GC2010Plus+AOC-20 autosampler gas chromatograph with a CP-SIL-5CB column connected to a flame ionization detector. EGB HS 600 Headspace apparatus was applied for sample preparation. The water concentration was measured with Hanna HI 904 coulometric Karl Fischer titrator [47-49].

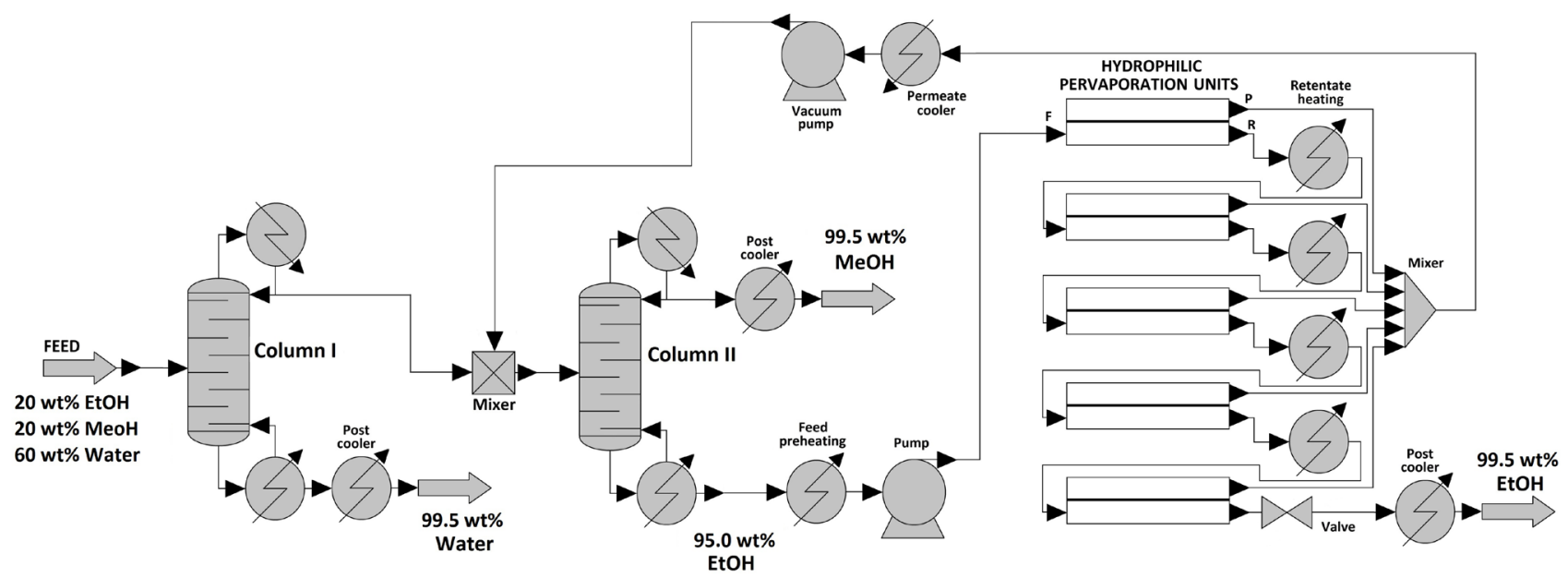

Fig. 1 Flowsheet of water-ethanol-methanol ternary mixture separation 


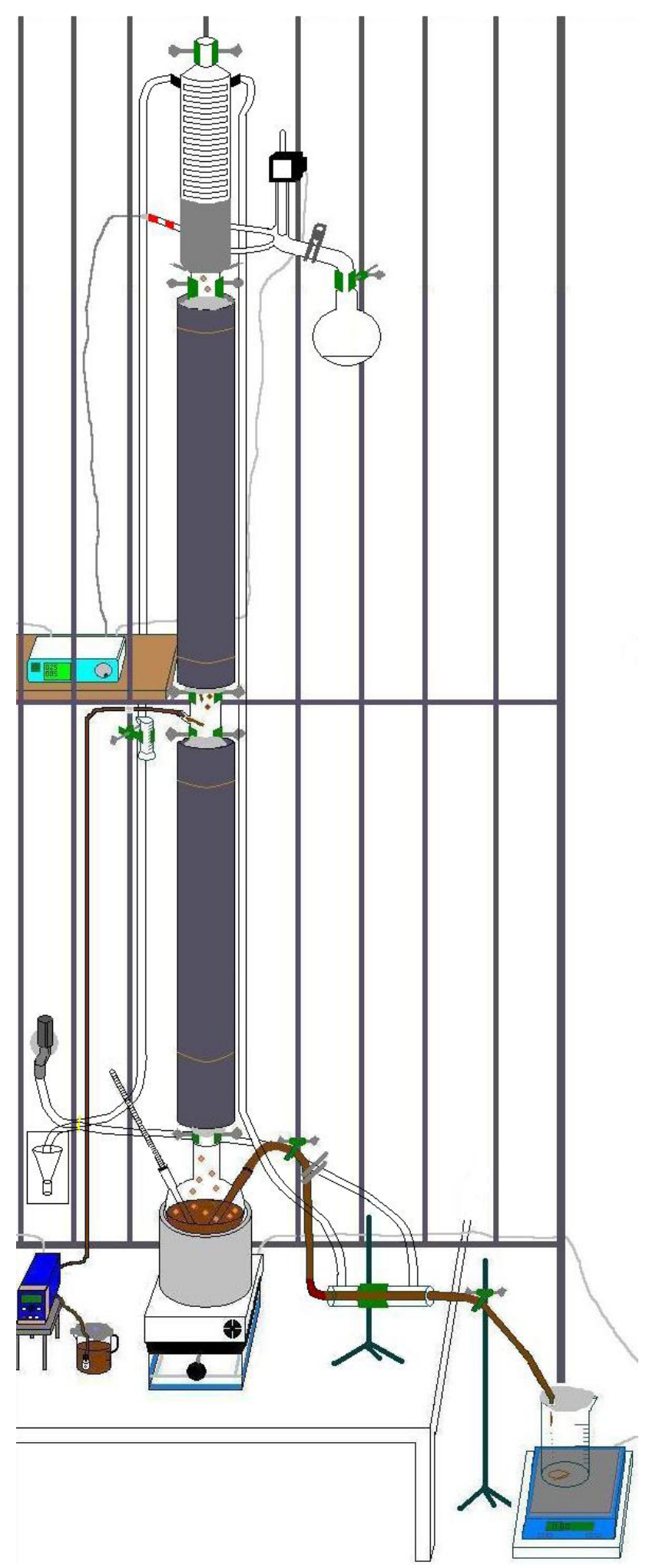

Fig. 2 Laboratory distillation column [11]

\section{Results and discussion}

\subsection{Experimental verification of distillation separation}

Table 5 shows the simulated and measured results of first distillation column (Column I). It can be seen the comparison presents the accuracy. The reflux ratio was 5 .
Table 5 Comparison of modelling and experimental data for ternary mixture with Column I

\begin{tabular}{lccccc}
\hline & Mixture & \multicolumn{2}{c}{ Modelling results } & \multicolumn{2}{c}{$\begin{array}{c}\text { Experimental } \\
\text { results }\end{array}$} \\
& feed & $D$ & $W$ & $D$ & $W$ \\
\hline EtOH [wt\%] & 20 & 47.4 & 0.3 & 47.3 & 0.2 \\
MeOH [wt\%] & 20 & 47.4 & 0.2 & 47.6 & 0.2 \\
Water [wt\%] & 60 & 5.3 & 99.5 & 5.1 & 99.6 \\
Stream [kg/h] & 0.5 & 0.21 & 0.29 & 0.19 & 0.31 \\
$T\left[{ }^{\circ} \mathrm{C}\right]$ & 20 & 70.2 & 99.1 & 70.0 & 99.3 \\
\hline
\end{tabular}

\subsection{Modelling results of flowsheet simulator}

The optimized results of simulations with distillation processes are listed in Table 6. It can be stated, the purity requirements $(99.5 \mathrm{wt} \%$ ) can be achieved using the hybrid method (see Fig. 1 too).

Table 7 introduces the optimized modelling results of hydrophilic pervaporation: membrane surface area, input and output streams of method. It can be concluded the basic Rautenbach model (Model I) underestimates the values in all cases.

It can be stated, the process design needs the evaluation of the heat demands at the different separation steps $[7,45]$. Table 8 includes the calculated heat duties of the hybrid method. It can be concluded that the reboiler of distillation columns have the highest heating requirement of the method.

\subsection{Cost estimation}

The conceptual design of an industrial tasks takes a small part of the project costs but recommends a huge cost reduction opportunity for the whole project $[7,45]$, therefore the investigated method should be investigated also from an economic point of view. Table 9 shows the main cost elements of the method.

Table 6 Modelling results of distillation columns

\begin{tabular}{lcc}
\hline & Column I & Column II \\
\hline Feed stream [kg/h] & 1000 & 420 \\
EtOH conc. in the feed [wt\%] & 20 & 47.1 \\
MeOH conc. in the feed [wt\%] & 20 & 47.4 \\
Reflux ratio [-] & 5 & 17 \\
Number of total theoretical stages [-] & 20 & 30 \\
Feed tray number [-] & 10 & 15 \\
EtOH conc. in the distillate [wt\%] & 48.6 & 0.5 \\
MeOH conc. in the distillate [wt\%] & 48.9 & 99.5 \\
Distillate temperature [ $\left.{ }^{\circ} \mathrm{C}\right]$ & 69.5 & 64.2 \\
\hline
\end{tabular}


Table 7 Modelling results of hydrophilic pervaporation

\begin{tabular}{ccccc}
\hline & & Model I & Model II & Deviation [\%] \\
\hline & $A_{\mathrm{PV}}\left[\mathrm{m}^{2}\right]$ & 60 & 65 & 8.3 \\
& $F[\mathrm{~kg} / \mathrm{h}]$ & 218.4 & 220.2 & 0.8 \\
\hline & $P[\mathrm{~kg} / \mathrm{h}]$ & 12.7 & 13.2 & 3.6 \\
\hline
\end{tabular}

Table 8 Calculated heat duties of hybrid separation method

\begin{tabular}{llcc}
\hline Calculated heat duties & $Q_{\text {Heating }}[\mathrm{MJ} / \mathrm{h}]$ & $Q_{\text {Cooling }}[\mathrm{MJ} / \mathrm{h}]$ \\
\hline \multirow{4}{*}{ Distillation } & Reboiler & 4150 & \\
& Condenser & & -4060 \\
& Post cooler & & -320 \\
\hline \multirow{5}{*}{ Pervaporation } & Feed preheating & 240 & \\
& Retentate heating & 330 & -250 \\
& Permeate cooler & & -90 \\
\hline
\end{tabular}

Table 9 Cost elements of hybrid separation method

\begin{tabular}{|c|c|c|c|c|c|}
\hline \multirow[b]{2}{*}{$\begin{array}{l}10 \text { years } \\
\text { amortization }\end{array}$} & \multicolumn{2}{|c|}{ Investment cost } & \multicolumn{2}{|c|}{ Operating cost } & \multirow{2}{*}{$\begin{array}{c}\text { TAC } \\
1000 \$ / \\
\text { year }\end{array}$} \\
\hline & $\begin{array}{l}1000 \$ / \\
\text { year }\end{array}$ & $\%$ & $\begin{array}{c}1000 \$ / \\
\text { year }\end{array}$ & $\%$ & \\
\hline $\begin{array}{l}\text { Distillation } \\
\text { column }\end{array}$ & 18.8 & 14 & - & - & 18.8 \\
\hline $\begin{array}{l}\text { Heat } \\
\text { exchangers }\end{array}$ & 31.1 & 23 & 229.2 & 79 & 260.3 \\
\hline $\begin{array}{l}\text { Membrane } \\
\text { modules }\end{array}$ & 81.2 & 60 & 23.2 & 8 & 104.4 \\
\hline $\begin{array}{l}\text { Permeate } \\
\text { cooling }\end{array}$ & 4.1 & 3 & 37.4 & 13 & 41.5 \\
\hline Pumps & 0.1 & $<0.5$ & 0.3 & $<0.5$ & 0.4 \\
\hline Total & 135.4 & & 290.1 & & 425.5 \\
\hline
\end{tabular}

It can be determined that the highest part of install cost is membrane modules and the utility cost of heat exchangers are the most significant part of total annual cost. This statement is consistent with other hybrid methods [7, 41].

\section{Conclusions}

The combination of distillation and pervaporation method is investigated in flowsheet environment. Semi-empirical models are used for modelling of pervaporation and the separation conditions of first distillation column are also verified with laboratory experiment. It can be concluded water-ethanol-methanol ternary mixture can be separated into pure components with the selected unit operations. The goal composition, which is $99.5 \mathrm{wt} \%$ in every product cases can be reached. The presented method is considered suitable for industrial applications.

\section{Acknowledgements}

This publication was supported by the János Bolyai Research Scholarship of the Hungarian Academy of Sciences, ÚNKP-19-4-BME-416 New National Excellence Program of the Ministry for Innovation and Technology, OTKA 131586, 112699 and 128543. This research was supported by the European Union and the Hungarian State, co-financed by the European Regional Development Fund in the framework of the GINOP-2.3.4-15-2016-00004 project, aimed to promote the cooperation between the higher education and the industry. The research reported in this paper has been supported by the National Research, Development and Innovation Fund (TUDFO/51757/2019ITM), Thematic Excellence Program.

\begin{tabular}{|c|c|}
\hline \multicolumn{2}{|c|}{ Nomenclature } \\
\hline$A$ & Membrane transfer area $\left[\mathrm{m}^{2}\right]$ \\
\hline$B$ & Constant in Model II [-] \\
\hline$D$ & Distillation product \\
\hline $\bar{D}_{i}$ & Transport coefficient of component $i\left[\mathrm{kmol} /\left(\mathrm{m}^{2} \times \mathrm{h}\right)\right]$ \\
\hline$F$ & Feed \\
\hline$i$ & Component number \\
\hline$j$ & Component number \\
\hline$J_{i}$ & Partial flux $\left[\mathrm{kg} /\left(\mathrm{m}^{2} \times \mathrm{h}\right)\right]$ \\
\hline$P$ & Permeate \\
\hline$p_{i 0}$ & Pure $i$ component vapour pressure [bar] \\
\hline$p_{i 1}$ & $\begin{array}{l}\text { Partial pressure of component } i \text { on the liquid } \\
\text { phase membrane side [bar] }\end{array}$ \\
\hline$p_{i 3}$ & $\begin{array}{l}\text { Partial pressure of component } i \text { on the vapor } \\
\text { phase membrane side [bar] }\end{array}$ \\
\hline$Q$ & Heat duty $[\mathrm{MJ} / \mathrm{h}]$ \\
\hline$Q_{0}$ & $\begin{array}{l}\text { Permeability coefficient of the porous support } \\
\text { layer of the membrane }\left[\mathrm{kmol} /\left(\mathrm{m}^{2} \times \mathrm{h} \times \text { bar }\right)\right]\end{array}$ \\
\hline$R$ & Retentate \\
\hline$T$ & Temperature $\left[{ }^{\circ} \mathrm{C}\right]$ \\
\hline$x_{i 1}$ & Concentration of component $i$ in the feed $[\mathrm{m} /(\mathrm{m} \%)]$ \\
\hline$W$ & Bottom product \\
\hline
\end{tabular}
Abbreviations
EtOH Ethanol
HPV Hydrophilic pervaporation
$\mathrm{MeOH}$ Methanol
OF Objective function
PV Pervaporation
PWW Process wastewater
TAC Total Annual Cost [1000\$/year]
VLE Vapor-Liquid Equilibrium
VOC Volatile organic compounds 


\section{Greek letters}

$\bar{\gamma}_{i} \quad$ Average activity coefficient of component $i$

\section{References}

[1] Xu, Z. K., Dai, Q. W., Liu, Z. M., Kou, R. Q., Xu, Y. Y. "Microporous polypropylene hollow fiber membranes: Part II. Pervaporation separation of water/ethanol mixtures by the poly(acrylic acid) grafted membranes", Journal of Membrane Science, 214(1), pp. 71-81, 2003. https://doi.org/10.1016/S0376-7388(02)00536-7

[2] Mohammadi, T., Aroujalian, A., Bakhshi, A. "Pervaporation of dilute alcoholic mixtures using PDMS membrane", Chemical Engineering Science, 60(7), pp. 1875-1880, 2005. https://doi.org/10.1016/j.ces.2004.11.039

[3] Tóth, A. J., Gergely, F., Mizsey, P. "Physicochemical treatment of pharmaceutical wastewater: distillation and membrane processes", Periodica Polytechnica Chemical Engineering, 55(2), pp. 59-67, 2011.

https://doi.org/10.3311/pp.ch.2011-2.03

[4] Mizsey, P., Tóth, A. J. "Application of the principles of industrial ecology for the treatment of process waste waters with physicochemical tools", Industrial Ecology, 1, pp. 101-126, 2012.

[5] Koczka, K. "Environmental conscious design and industrial application of separation processes", PhD Thesis, Budapest University of Technology and Economics, 2009.

[6] Koczka, K., Mizsey, P. "New area for distillation: wastewater treatment", Periodica Polytechnica Chemical Engineering, 54(1), pp. 41-45, 2010.

https://doi.org/10.3311/pp.ch.2010-1.06

[7] Tóth, A. J., Haáz, E., Nagy, T., Tarjáni, A. J., Fózer, D., André, A., Valentinyi, N., Solti, S., Mizsey, P. "Treatment of Pharmaceutical Process Wastewater with Hybrid Separation Method: Distillation and Hydrophilic Pervaporation", Waste Treatment and Recovery, 3(1), pp. 8-13, 2018.

https://doi.org/10.1515/wtr-2018-0002

[8] Tóth, A. J., Haáz, E., Nagy, T., Tarjáni, A. J., Fózer, D., André, A., Valentínyi, N., Mizsey, P. "Novel method for the removal of organic halogens from process wastewaters enabling water reuse", Desalination and Water Treatment, 130, pp. 54-62, 2018.

https://doi.org/10.5004/dwt.2018.22987

[9] Tóth, A. J., Haáz, E., Szilágyi, B., Nagy, T., Tarjáni, A. J., Fózer, D., André, A., Valentínyi, N., Solti, S., Mizsey, P. "COD reduction of process wastewater with vacuum evaporation", Waste Treatment and Recovery, 3(1), pp. 1-7, 2018.

https://doi.org/10.1515/wtr-2018-0001

[10] Marsden, C. "Solvents And Allied Substances Manual With Solubility Chart", Cleaver-Hume Press, London, UK, 1954.

[11] Tóth, A. J. "Liquid Waste Treatment with Physicochemical Tools for Environmental Protection", PhD Thesis, Budapest University of Technology and Economics, 2015.

[12] Favre, E. "Temperature polarization in pervaporation", Desalination, 154(2), pp. 129-138, 2003. https://doi.org/10.1016/S0011-9164(03)80013-9
[13] Hasanoğlu, A., Salt, Y., Keleşer, S., Özkan, S., Dinçer, S. "Pervaporation separation of organics from multicomponent aqueous mixtures", Chemical Engineering and Processing: Process Intensification, 46(4), pp. 300-306, 2007. https://doi.org/10.1016/j.cep.2006.06.010

[14] Rautenbach, R., Herion, C., Meyer-Blumentoth, U. "Pervaporation membrane separation processes", Membrane Science and Technology Series, Elsevier, Amsterdam, Netherlands, 1990, pp. 181-191.

[15] Valentínyi, N., Cséfalvay, E., Mizsey, P. "Modelling of pervaporation: Parameter estimation and model development", Chemical Engineering Research and Design, 91(1), pp. 174-183, 2013. https://doi.org/10.1016/j.cherd.2012.07.001

[16] Baker, R. W. "Membrane Technology and Applications", John Wiley \& Sons Ltd., Chichester, UK, 2012. https://doi.org/10.1002/9781118359686

[17] Jonquières, A., Clément, R., Lochon, P., Néel, J., Dresch, M., Chrétien, B. "Industrial state-of-the-art of pervaporation and vapour permeation in the western countries", Journal of Membrane Science, 206(1-2), pp. 87-117, 2002. https://doi.org/10.1016/S0376-7388(01)00768-2

[18] Hsueh, C. L., Kuo, J. F., Huang, Y. H., Wang, C. C., Chen, C. Y. "Separation of ethanol-water solution by poly(acrylonitrile-co-acrylic acid) membranes", Separation and Purification Technology, 41(1), pp. 39-47, 2005. https://doi.org/10.1016/j.seppur.2004.04.002

[19] Koczka, K., Mizsey, P., Fonyó, Z. "Rigorous modelling and optimization of hybrid separation processes based on pervaporation", Central European Journal of Chemistry, 5(4), pp. 1124-1147, 2007. https://doi.org/10.2478/s11532-007-0050-8

[20] Lipnizki, F., Field, R. W. "Simulation and Process Design of Pervaporation Plate-and-Frame Modules to Recover Organic Compounds from Waste Water", Chemical Engineering Research and Design, 77(3), pp. 231-240, 1999. https://oi.org/10.1205/026387699526142

[21] Konieczny, K., Bodzek, M., Panek, D. "Removal of volatile compounds from the wastewaters by use of pervaporation", Desalination, 223(1-3), pp. 344-348, 2008. https://doi.org/10.1016/j.desal.2007.01.211

[22] Lipnizki, F., Hausmanns, S., Ten, P. K., Field, R. W., Laufenberg, G. "Organophilic pervaporation: Prospects and performance", Chemical Engineering Journal, 73(2), pp. 113-129, 1999. https://doi.org/10.1016/S1385-8947(99)00024-8

[23] Aroujalian, A., Belkacemi, K., Davids, S. J., Turcotte, G., Pouliot, Y. "Effect of Protein on Flux and Selectivity in Pervaporation of Ethanol from a Dilute Solution", Separation Science and Technology, 38(12-13), pp. 3239-3247, 2003. https://doi.org/10.1081/SS-120022596 
[24] Cunha, V. S., Paredes, M. L. L., Borges, C. P., Habert, A. C., Nobrega, R. "Removal of aromatics from multicomponent organic mixtures by pervaporation using polyurethane membranes: Experimental and modeling", Journal of Membrane Science, 206(1-2), pp. 277-290, 2002. https://doi.org/10.1016/S0376-7388(01)00776-1

[25] Kuila, S. B., Ray, S. K. "Sorption and permeation studies of tetrahydrofuran-water mixtures using full interpenetrating network membranes", Separation and Purification Technology, 89, pp. 39-50, 2012.

https://doi.org/10.1016/j.seppur.2012.01.005

[26] Smitha, B., Suhanya, D., Sridhar, S., Ramakrishna, M. "Separation of organic-organic mixtures by pervaporation-a review", Journal of Membrane Science, 241(1), pp. 1-21, 2004. https://doi.org/10.1016/j.memsci.2004.03.042

[27] Nguyen, T. Q., Nobe, K. "Extraction of organic contaminants in aqueous solutions by pervaporation", Journal of Membrane Science, 30(1), pp. 11-22, 1987. https://doi.org/10.1016/S0376-7388(00)83337-2

[28] Devaine, K. M., Meier, A. J., Slater, C. S. "Pervaporation for the recovery of MEK and other solvents using organophilic membranes", In: Bakish, R. (ed.) Seventh International Conference on Pervaporation Process in the ChemicalIndustry, Bakish Materials Corp., Reno, NV, USA, 1995, pp. 218-219.

[29] Zhang, S. Q., Fouda, A. E., Matsuura, T. "A study on pervaporation of aqueous benzyl alcohol solution by polydimethylsiloxane membrane", Journal of Membrane Science, 70(2-3), pp. 249-255, 1992. https://doi.org/10.1016/0376-7388(92)80110-6

[30] Tóth, A. J. "Comprehensive evaluation and comparison of advanced separation methods on the separation of ethyl acetate-ethanol-water highly non-ideal mixture", Separation and Purification Technology, 224, pp. 490-508, 2019.

https://doi.org/10.1016/j.seppur.2019.05.051

[31] Willemsen, J. H. A., Dijkink, B. H., Togtema, A. "Organophilic pervaporation for aroma isolation - industrial and commercial prospects", Membrane Technology, 2004(2), pp. 5-10, 2004. https://doi.org/10.1016/S0958-2118(04)00082-5

[32] Mizsey, P., Koczka, K., Tungler, A. "Treatment of process waters with physicochemical techniques", Hungarian Journal of Chemistry, 114, pp. 107-113, 2008.

[33] Fleming, H. L., Slater, C. S. "Pervaporation", Springer, New York, NY, USA, 1992.

[34] Liu, Q., Noble, R. D., Falconer, J. L., Funke, H. H. "Organics/water separation by pervaporation with a zeolite membrane", Journal of Membrane Science, 117(1-2), pp. 163-174, 1996. https://doi.org/10.1016/0376-7388(96)00058-0

[35] Bowen, T. C., Kalipcilar, H., Falconer, J. L., Noble, R. D. "Pervaporation of organic/water mixtures through B-ZSM-5 zeolite membranes on monolith supports", Journal of Membrane Science, 215(1-2), pp. 235-247, 2003. https://doi.org/10.1016/S0376-7388(02)00617-8

[36] Mizsey, P., Szanyi, Á., Raab, A., Manczinger, J., Fonyó, Z. "Intensification of a Solvent Recovery Technology through the Use of Hybrid Equipment", Computer Aided Chemical Engineering, 10, pp. 121-126, 2002.

https://doi.org/10.1016/S1570-7946(02)80048-7
[37] Wijmans, J. G., Baker, R. W. "The solution-diffusion model: a review", Journal of Membrane Science, 107(1-2), pp. 1-21, 1995. https://doi.org/10.1016/0376-7388(95)00102-I

[38] André, A., Nagy, T., Tóth, A. J., Haáz, E., Fózer, D., Tarjáni, A. J., Mizsey, P. "Distillation contra pervaporation: Comprehensive investigation of isobutanol-water separation", Journal of Cleaner Production, 187, pp. 804-818, 2018.

https://doi.org/10.1016/j.jclepro.2018.02.157

[39] Haáz, E., Tóth, A. J. "Methanol dehydration with pervaporation: Experiments and modelling", Separation and Purification Technology, 205, pp. 121-129, 2018. https://doi.org/10.1016/j.seppur.2018.04.088

[40] Li, S., Tuan, V. A., Falconer, J. L., Noble, R. D. "Properties and separation performance of Ge-ZSM-5 membranes", Microporous and Mesoporous Materials, 58(2), pp. 137-154, 2003. https://doi.org/10.1016/S1387-1811(02)00612-1

[41] Valentínyi, N., Mizsey, P. "Comparison of pervaporation models with simulation of hybrid separation processes", Periodica Polytechnica Chemical Engineering, 58(1), pp. 7-14, 2014. https://doi.org/10.3311/PPch.7120

[42] Haáz, E., Valentínyi, N., Tarjáni, A. J., Fózer, D., André, A., Mohamed, S. A. K., Rahimli, F., Nagy, T., Mizsey, P., Deák, C., Tóth, A. J. "Platform Molecule Removal from Aqueous Mixture with Organophilic Pervaporation: Experiments and Modelling", Periodica Polytechnica Chemical Engineering, 63(1), pp. 138-146, 2019. https://doi.org/10.3311/PPch.12151

[43] Douglas, J. M. "Conceptual design of chemical processes", McGraw-Hill, New York, NY, USA, 1988. https://doi.org/10.1002/jctb.280460308

[44] Castillo, I. "Inventory Index Factors", [online] Available at: https://www.scribd.com/document/395480214/2018-BPP-Index-ServiceLife-Depreciation [Accessed: 27 October 2019]

[45] Tóth, A. J., André, A., Haáz, E., Mizsey, P. "New horizon for the membrane separation: Combination of organophilic and hydrophilic pervaporations", Separation and Purification Technology, 156(2), pp. 432-443, 2015.

https://doi.org/10.1016/j.seppur.2015.10.032

[46] Tusel, G. F., Brüschke, H. E. A. "Use of pervaporation systems in the chemical industry", Desalination, 53(1-3), pp. 327-338, 1985. https://doi.org/10.1016/0011-9164(85)85070-0

[47] Tóth, A. J., Szanyi, Á., Koczka, K., Mizsey, P. "Enhanced separation of highly non-ideal mixtures with extractive heterogeneous-azeotropic distillation", Separation Science and Technology, 51(7), pp. 1238-1247, 2016. https://doi.org/10.1080/01496395.2015.1107099

[48] Tóth, A. J., Szanyi, Á., Haáz, E., Mizsey, P. "Separation of Process Wastewater with Extractive Heterogeneous-azeotropic Distillation", Hungarian Journal of Industry and Chemistry, 44(1), pp. 29-32, 2016. https://doi.org/10.1515/hjic-2016-0003

[49] Tóth, A. J., Haáz, E., Nagy, T., Tari, R., Tarjáni, A. J., Fózer, D., Szanyi, Á., Koczka, K., Rácz, L., Ugro, G., Mizsey, P. "Evaluation of the accuracy of modelling the separation of highly non-ideal mixtures: extractive heterogeneous-azeotropic distillation", Computer Aided Chemical Engineering, 40, pp. 241-246, 2017. https://doi.org/10.1016/B978-0-444-63965-3.50042-8 